\title{
Future Language Teachers as Experts in the Subject: Developing Cultural Content Knowledge in Teacher Education
}

\author{
Mathea Simons \\ Academic Teacher Training, Institute of Education and Information Sciences, University of Antwerp, Antwerp, \\ Belgium
}

\begin{abstract}
Teachers have many roles to fulfill. One of the most important roles is that of expert in the subject field they teach. Teachers should master the contents of the subject and should be able to deepen understanding and insight in these contents. Language teachers do not only teach the foreign language. They are also responsible for the teaching of the culture of the language. This article reports on a project on cultural content knowledge of future language teachers in teacher education. The project establishes that testing instruments and remediation materials are more effective when adapted to the future target context. Culture is a wide concept. Selecting the basic contents in manuals which are students' future working material appears to contribute to their motivation. Moreover, the meaning of culture is twofold as it can be split into Culture with a capital $c$ and culture with a small $c$. If we want to contribute to intercultural language teaching, both components need to be addressed.
\end{abstract}

Index Terms - teacher education, foreign language teaching, cultural content knowledge, assessment, remediation

\section{TEACHERS AS EXPERTS OF THE SUBJECT}

\section{A. One Teacher, Many Roles}

A teacher has many roles to fulfill. In their description of the "ideal teacher" Van Gennip and Vrieze (2008) divide teachers' roles into three interacting categories: specific content knowledge, interventions and person.

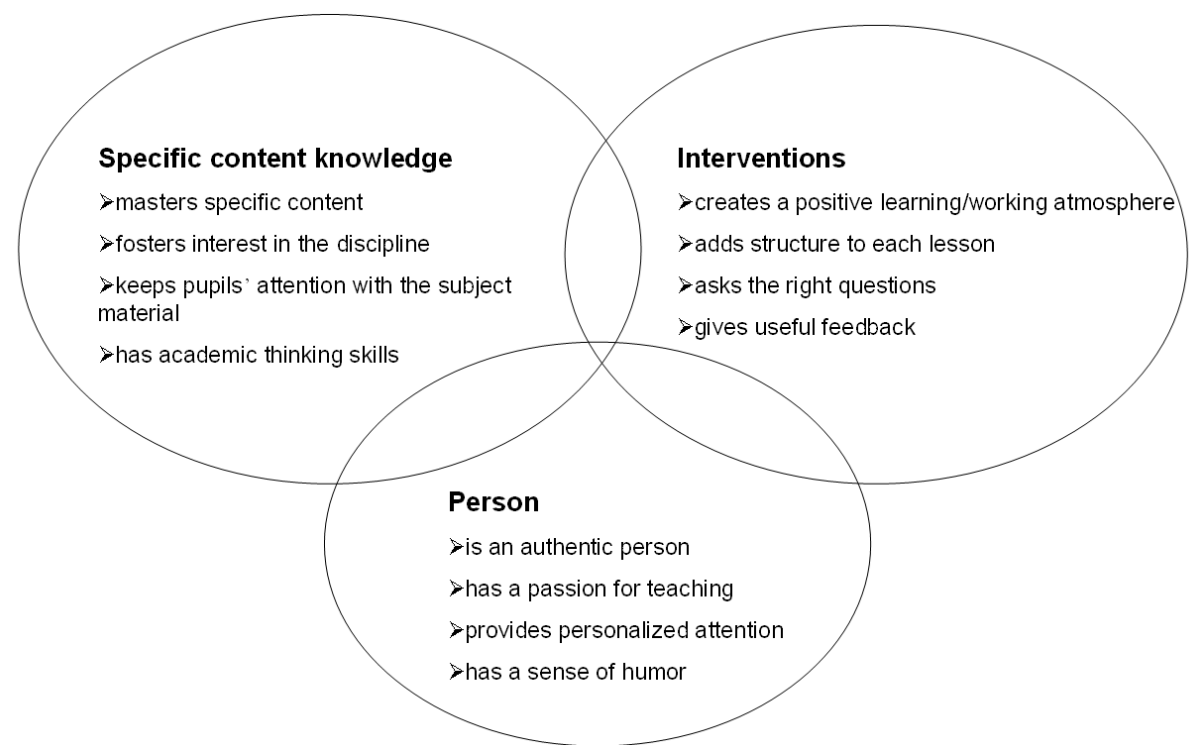

Figure1. Quality model of Van Gennip \& Vrieze (2008)

Van Gennip and Vrieze (2008, p.7) suppose that no teaching is possible without specific content, that there is no effect on learners without the adequate educational interventions, and that class management suffers from the lack of the right personal characteristics. This threefold division is also established by previous research (i.e. Verloop 1999, 2003; Verloop, van Driel \& Meijer 2001; Van Essen \& Timmerman, 2007). There is a difference in the learnability of the components. Specific content knowledge is the most learnable. (Didactic) interventions suppose some challenge but are also quite learnable. As for the person of the teacher, there is ample space for improvement, even though this is less evident (Van Gennip \& Vrieze, 2008). 


\section{B. Expertise of the Subject}

There is vast consensus on the fact that teachers ought to be content experts and master subject matter. Kamp (2007) refers to some research showing that teachers with sound content knowledge are able to identify learners' initial knowledge, ask better questions, give better instructions and allow more contributions from learners. In such a perspective, content knowledge appears as a key to teachers' autonomy.

The importance of the role of expert in the subject is emphasized in numerous studies (e.g. Hill e.a. 2005; Kendall \& Marzano, 1997; Kleickmann e.a. 2013; Loewenberg Ball e.a. 2008) and in many countries this role is an essential part of the Competences profile of future teachers and/or the Teachers' career profile.

The role of expert in the subject is correlated with teachers' knowledge of the subject they are to teach. This is the knowledge-oriented dimension, i.e. the teacher as expert in the content. Shulman (1999) makes an inventory of the seven types of knowledge teachers should have at their disposal: content knowledge, general pedagogical knowledge, curriculum knowledge, pedagogical content knowledge, knowledge of learners, knowledge of educational contexts and knowledge of educational ends. This article focuses on the first kind of knowledge. Shulman refers to Bruner (1967) defining content knowledge as 'the theories, principles, and concepts of a particular discipline.' This basic knowledge is related to the teachers' initial training (in all its forms) and, later, to teachers' continuing education.

There is an interface between content knowledge and pedagogical content knowledge. Shulman defines it as follows: '[Pedagogical content knowledge] represents the blending of content and pedagogy into an understanding of how particular topics, problems or issues are organized, represented, and adapted to the diverse interests and abilities of learners, and presented for instruction.' (Shulman, 1999, p.66). Depending on the content, teachers ought to be able to judge which approach is the most adequate, taking into consideration the moment, the specificities of the learners and the context. Aside from this, they are also expected to know how they can monitor and evaluate learners (Van Driel, 2009). Content knowledge goes before pedagogical content knowledge. It is evident that before passing on content in an adequate way, teachers must first master the content themselves.

\section{Content Knowledge of Starting Teachers: A Current Concern}

There is growing concern about (starting) teachers' basic content knowledge of the subject (Kamp, 2007). Several subjects are affected. The following can be quoted as telling examples: the unsatisfactory language skills among primary education teachers (Onderwijsinspectie, 2004; Edulex, BaO/2005/01; Feys \& Gybels, 2006) or the limited calculation skills of the upcoming generation of primary school teachers (Van der Neut, 2007; Heather e.a. 2005).

As regards the causes of decreasing content-specific knowledge, some point to student inflow in teacher education that is more diverse than in the past and increasingly generates from technical or vocational education. Others look in the direction of the output. As the financing of tertiary education in several European countries is highly dependent on the output, i.e. the number of graduations, the pressure on content-specific knowledge would have lowered. The media have joined in the debate and aspects of the problem are sometimes considered as finding their cause in teacher education (e.g. Van Essen \& Timmerman, 2007; Kamp, 2007).

Does teacher education pay enough attention to the basic subject-specific knowledge of pre-service teachers (Grossman 1990, Kleickmann e.a. 2013)? Some teacher education curricula pay great attention to the disciplinary component of the function. This is mainly the case for integrated teacher training programmes in which content knowledge and pedagogical knowledge are closely knitted. Other curricula are based on the assumption that specific content knowledge has already been acquired before starting teacher education and that it is better to focus mainly (casu quo only) on the specific pedagogical and didactic knowledge. This is often the case for (postgraduate) teacher education programmes in which the main focus is on pedagogical content knowledge, as it is assumed that content knowledge of the subject itself has already been acquired.

In this article, we focus on the expertise we can expect from future teachers of French as a foreign language in the last years of secondary education. The institutional context is a one year teacher education programme for students who have already obtained their master degree (= postgraduate programme).

\section{Language Teachers $=$ Teachers in Language and Culture}

Language teachers' basic subject content knowledge relates on the one side to knowledge of the target language itself, i.e. the basic linguistic knowledge. This includes both oral and written competences, but also an analytic insight in the lexicon, grammar, and language pragmatics, so that they might immediately identify the causes lying behind students' mistakes and propose adequate remediation. On the other hand, language teachers are also expected to impart cultural knowledge as well as intercultural attitudes and competences. This explains why the literature favours the term of "language and culture teacher" as coined by Byram and Morgan (1994) rather than that of "language teacher". At cultural level, language teachers will help their students build on a background of positively registered cultural knowledge and experience, thereby stimulating higher levels of intercultural competence. Such a systematic approach and enrichment of their cultural background over several school years works as a jigsaw: the more you complete it, the more it will render the coherence and harmoniousness of the studied language.

As regards the content and objectives of cultural education itself, an important evolution can be observed. Until the 1960 's the first aim was to get acquainted with the cultural heritage of the target language (literature, masterpieces). From the 60's onwards, popular culture - i.e. traditions, habits, attitudes etc. - were progressively included in cultural 
education and pupils/students were encouraged to reflect on their own culture. Later on, cultural education would grow into intercultural foreign language education (Sercu, 2006). Liddicoat e.a. (2003) refer to Byram and Zarate's (1994) list of objectives in foreign language learning:

1. Knowledge (Savoir): individual and societal knowledge of own and foreign culture;

2. Knowing as understanding (Savoir-Comprendre): competences for interpreting and accounting for information:

3. Knowing as learning/doing (Savoir-Apprendre/Faire): competences for discovering and acquiring

4. Knowing as being (Savoir-Etre): attitude towards own culture and foreign culture

5. Knowing as commitment (Savoir-S'engager): developing a critical attitude and a social conscience

In order to reach these objectives, language teachers need to develop their own specific knowledge, attitudes and competences.

Present day (foreign) language teachers have mainly been trained as "language teachers" and less as "language and culture teachers". Consequently the knowledge, skills and competences they have acquired during their (teacher) training are first aimed at the efficient organisation of foreign language teaching and the cultural element is less central (Sercu, 2006).

This article focuses on the acquisition of cultural basic knowledge (i.e. Savoirs cf. supra point 1). We are aware that this is only a first step on the way to our final objective, i.e. training our teachers to develop their own intercultural foreign language teaching skills and pass them on. However, it is necessary to work on teachers' basic cultural knowledge before considering the broader problem of their acquisition of (inter)cultural competences. It is therefore a first step, but its importance should not be underestimated (cf. the review study by Byram \&Feng, 2004).

\section{Working On BAsic CUltural KnOwledge During TeACher Training: The ConteXT}

The course Didactics of French (FLE - français langue étrangère) at the University of Antwerp includes a diagnostic analysis of the initial situation at the start of the programme. This analysis relies on two kinds of tests: a language test and a culture test.

Until recently, i.e. before the project described in this article was implemented, the initial culture test was a written one. Test items were calibrated on several levels (productive and receptive) and both active and passive knowledge were evaluated. Nevertheless, the choice of test items was open for improvement as the items exclusively referred to Cultural elements (Culture with a capital letter) and were selected only on the basis of intuition of the team members involved in the course module. If the test revealed shortcomings in language or in culture, remediation was left to students' own initiative (although reference books were provided). The initial situation analysis did not entail further consequences.

In recent years the need of a well-founded testing instrument for culture as well as for follow-up in the form of remediation has become more salient. The level of incoming students in the course module is increasingly heterogeneous (there is greater diversity among the students, implying more varied content preparation). The course module is accessible to Masters (from Universities or Higher Institutes) with 60 credits (ECTS) in the target language as well as to students (academic) Bachelors still in their Master years, provided they acquire 60 ECTS in the target language by the end of their training. Students from varied backgrounds are accepted: Film and theatre sciences, Literature of the Modernity, Multilingual Business Communication, Language and Literature Studies, Applied Linguistics, Translation and Interpretations (with French as a major or as a minor language). Some students follow the main trajectory. The others, following a LIO-baan traject (= studying \& teaching), are requested to participate to (part of) the practical component of the training while taking up a teaching assignment. Besides, the course module also attracts a high number of working students.

The main objective of the course module and of its practical component is to provide a theoretical and practical frame of reference thanks to which students learn how to teach French. The target context is secondary education, but the course also prepares to teach in continuing education.

There is a growing lack of balance between the contents that future teachers are expected to teach and students' actual active knowledge. In order to ensure teachers are informed from the onset, to raise awareness among them, and to allow them to acquire the expected knowledge in French culture during their training, we developed an assessment instrument (Section III. of this article) as well as matching remedial material (Section IV.). We also searched ways to integrate cultural knowledge in the curriculum (Section V.).

\section{DEVElOPMENT OF AN ASSESSMENT INSTRUMENT FOR CUlTURE}

\section{A. Contents}

Prior to working on the assessment instrument itself, we deemed it necessary to make an inventory of all the cultural elements in textbooks for secondary and continuing/adult education. Cultural knowledge is indeed a broad concept that allows a wide variety in content. We thought it best to acquaint students as thoroughly as possible with the elements they will be expected to teach in their future career. Therefore we decided to use French manuals as a corpus.

We based ourselves on 10 series of textbooks frequently used in secondary and adult education (in Flanders, Belgium): Arcades, Arcades Réseau, Branché, Concorde, En ligne, En scène, Étapes, Parcours, Pourquoi Pas and 
Rond-Point. We took into account all the available learning material in these series: elementary books, workbooks, user guides for teachers, listening material etc. The basic corpus for our inventory comprised 78 separate sources.

The initial inventory included 1700 cultural items. These items were further categorized and converted into a databank of 834 test items. The following table shows the test items divided into content areas and levels.

TABLE 1.

CLASSIFICATION OF TEST ITEMS IN CONTENT AREAS AND LEVELS

\begin{tabular}{|l|l|l|l|l|l|}
\hline & Level 4 (= lowest) & Level 3 & Level 2 & Level 1 (=highest) & Total \\
\hline BD - bande dessinée (Comics) & 6 & 9 & 0 & 1 & 16 \\
\hline Chanson (Songs) & 42 & 17 & 25 & 22 & 106 \\
\hline Cinéma & 4 & 3 & 22 & 11 & 40 \\
\hline Gastronomie & 10 & 5 & 7 & 6 & 28 \\
\hline Géographie & 22 & 5 & 3 & 2 & 32 \\
\hline Histoire & 41 & 20 & 93 & 36 & 190 \\
\hline Littérature & 7 & 19 & 83 & 167 & 276 \\
\hline Monuments & 10 & 40 & 5 & 6 & 61 \\
\hline Peinture & 3 & 10 & 9 & 12 & 34 \\
\hline Société & 16 & 10 & 6 & 17 & 51 \\
\hline Total & 162 & 139 & 253 & 280 & 834 \\
\hline
\end{tabular}

A level of difficulty between 1 (= highest level) and 4 (=lowest level) was assigned to each test item. This would allow students to be tested on a growing scale. The degree of difficulty of the questions was mainly fixed according to the presence of the tested items in the textbooks used in the study (i.e. level of difficulty based on intended educational level). The cultural items that are introduced in the lower years of French teaching (lower years in secondary and adult education) were classed under levels 4 and 3. The cultural items presented in the higher years (higher years in secondary education; advanced levels in adult education) were allotted to levels 2 and 1 (= highest level).

The level of difficulty of the items was also further determined by the intended fluency. Levels 4 and 2 contain items testing the receptive knowledge of cultural items. Levels 3 and 1 list items related to productive knowledge. In order to gauge receptive knowledge, the question types included multiple choice, association and classifying exercises. Productive dominion was tested with open questions.

Aside from defining the level of difficulty, building the evaluation system and establishing the intended competences, the following criteria were also taken into account in the production of the evaluation system: length of the item, feedback modalities, relatability of items and integration of media (image, audio and text).

The content of the assessment instrument can be typified as follows:

- Assessment instrument consisting of a question pool of 836 test items;

- Test items classified into 10 content areas;

- Test items classified according to difficulty level and intended fluency:

- Level 4: receptive knowledge: lower years of secondary and adult education;

- Level 3: productive knowledge: lower years of secondary and adult education;

- Level 2: receptive knowledge: higher years of secondary and adult education;

- Level 1: productive knowledge: higher years of secondary and adult education.

\section{B. Technical Specification}

We chose to administer the test on Blackboard. However, the test items were stocked in an independent database structure (Access), which allows us to use the same test contents for other devices or objectives.

The specification of the assessment instrument was made on the basis of the following elements:

- Blackboard does not provide advanced adaptive routines based on a detailed analysis of the individual test items. The adaptivity of Blackboard is restricted to testing itself. Therefore we opted for a semi-adaptive trajectory on Blackboard. Students start at level 4 and can gradually progress to level 1.

- There is a Blackboard test for each level. These tests consist of a number of 'random blocks' i.e. a selection of questions chosen at random from a pool of questions for a specific level and a specific content area (e.g. level $4-$ Chanson; see also Table 2). For each block of questions, we specified the number of questions that were taken from the pools. During the test, the question blocks were presented at random. In this way, students can use the assessment instrument several times without having to do the same test.

- For each level, we fixed a threshold or cut score. If students reach the cut score, they can move up to the next level. If they don't, they will have to do the level again or all over again. Students are allowed an unlimited number of attempts per level. However, there is a time limitation for the whole test, i.e. 1 hour, as well as a time limitation for each attempt, i.e. 25 minutes per level.

- After each attempt at reaching a level, students are granted an estimation of their score (e.g. "you will have to do this level again/ you can go on", completed with an indication of their score (red bar/ orange bar/ green bar).

- At the conclusion of the full test, students receive a global report, with the mention of the percentage reached per level. 


\section{Test Progress}

When loading a specific test, a selection of 25 questions per level is made, distributed over the content areas in a balanced way:

TABLE 2.

CLASSIFICATION OF ITEMS FOR A SPECIFIC TEST IN CONTENT AREAS AND LEVELS

\begin{tabular}{|l|l|l|l|l|}
\hline & Level 4 (= lowest) & Level 3 & Level 2 & Level 1 (=highest) \\
\hline BD - bande dessinée & 1 & 2 & 0 & 1 \\
\hline Chanson & 6 & 3 & 2 & 2 \\
\hline Cinéma & 1 & 1 & 2 & 1 \\
\hline Gastronomie & 2 & 1 & 1 & 1 \\
\hline Géographie & 3 & 1 & 1 & 1 \\
\hline Histoire & 6 & 3 & 8 & 3 \\
\hline Littérature & 1 & 3 & 8 & 13 \\
\hline Monuments & 2 & 7 & 1 & 1 \\
\hline Peinture & 1 & 2 & 1 & 1 \\
\hline Société & 2 & 2 & 1 & 1 \\
\hline Total & 25 & 25 & 25 & 25 \\
\hline
\end{tabular}

The following figure gives an idea of the global test progress. R refers to the result (latest result, mean result of all the tests or first result).

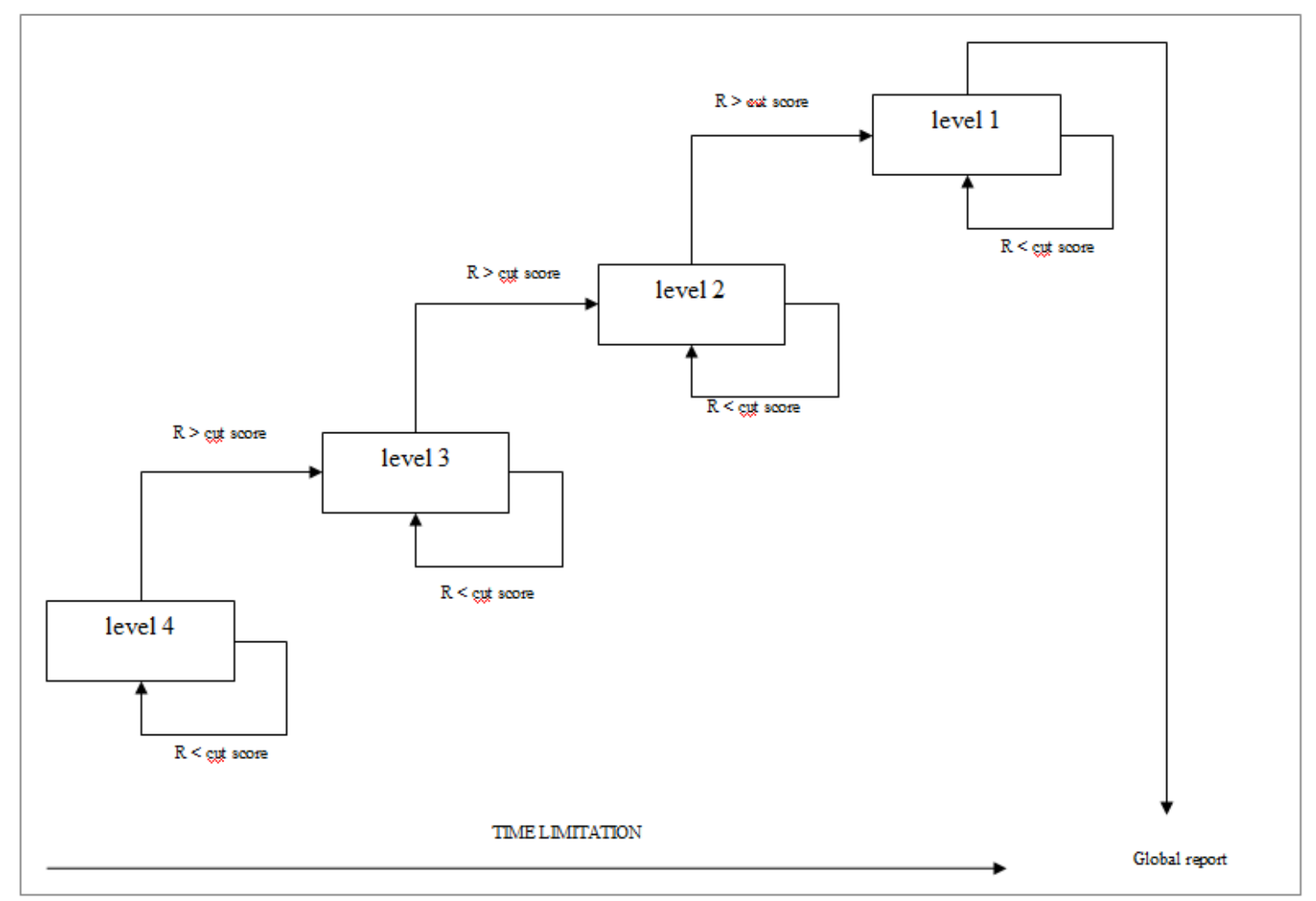

Figure2. Progress of a semi-adaptive test in Blackboard

If student don't pass the cut score ( $\mathrm{R}<$ cut score), they have to do a test at the same level. If they pass the cut score $(\mathrm{R}>$ cut score) they can go further to the next level. At the end of the test, they receive a global report detailing the given answers and providing an idea of the problematic areas of knowledge.

Combined to level content, this is what is obtained for a test at level 4 (test = collection of random blocks):

- random block 1: 1 question selected out of the question pool "level 4 -BD"

- random block 2: 6 questions selected out of the question pool "level 4 - chanson"

- random block $\mathrm{n}$ : $\mathrm{x}$ questions selected out of the question pool "level $\mathrm{x}$ - content area $\mathrm{x}$ "

The following figure gives an idea of some of the test items as well as of the lay-out of the test. 


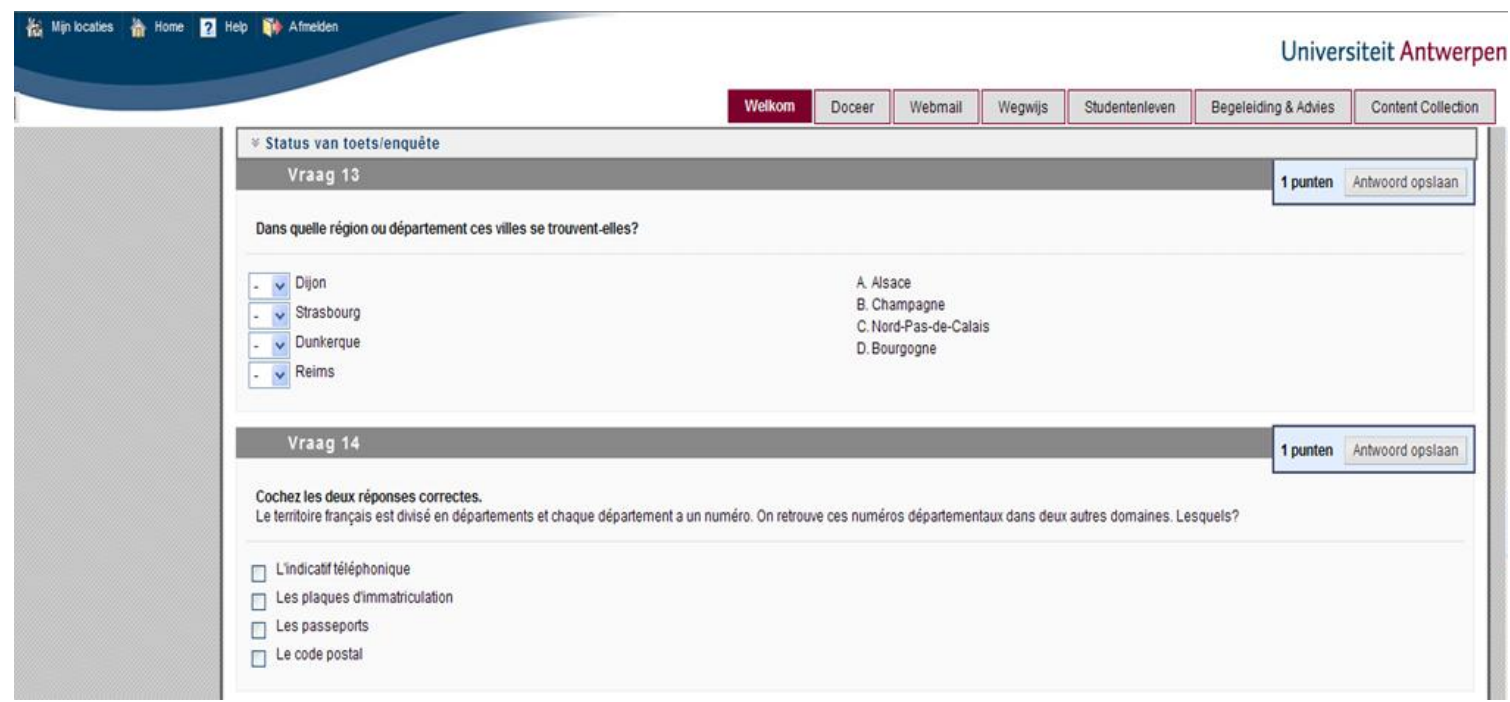

Figure3. Example of test items

In the last phase, the assessment instrument was tested and updated. To this purpose, pilot versions were given to students in French didactics $(n=18)$, teaching assistants $(n=2)$ and teachers of French $(n=4)$.

\section{Development of Remedial Material}

A flaw in the previous system of diagnostic analysis of the initial situation was the lack of follow-up (cf. Section 2 of this article). After the gaps in content were identified, remediation was left to students' own initiative. While developing the assessment instrument for culture, we therefore decided to work on providing extra remediation material.

When students don't pass the assessment test, they have to follow a remediation trajectory, but only in the domains in which shortcomings were observed. This is the case, for instance, if a student scores high on the content areas Cinéma, Gastronomie, Géographie, Histoire, Littérature and Monuments, but doesn't reach the minimum level for the content areas BD, Chanson, Peinture and Société. Such a student will have to follow a remediation trajectory in the latter content areas alone. In order to prepare students specifically to the contents as tested by the assessment instrument, we chose to provide them with remediation trajectories in the form of electronic workbooks and therefore designed one workbook per content area. In these self-study workbooks, the basis items were collected as they were inventoried in the initial database.

Figure 4 and 5 show items of the remedial material for Géographie and Chanson.

5. A chaque région, sa spécialité. Associez ces plats français à leur région d'origine. Puis, placez-les sur la carte.

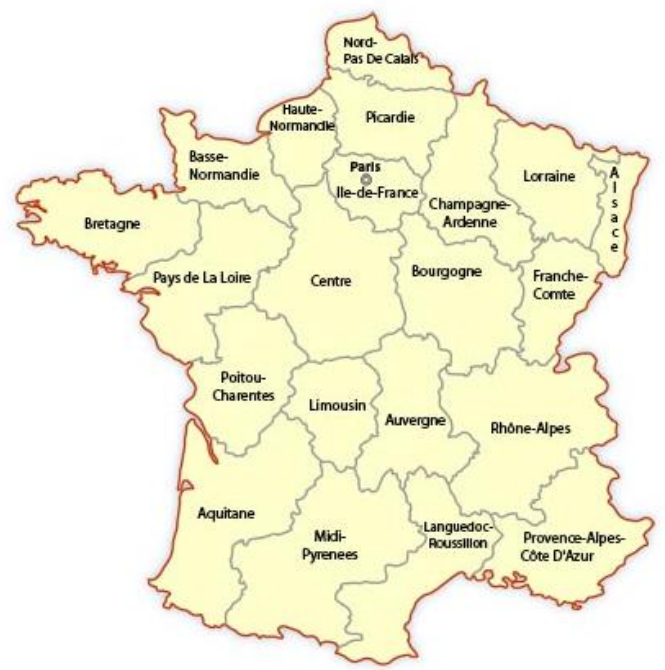

\begin{tabular}{|l|l|}
\hline \multicolumn{1}{|c|}{ Les régions } & \multicolumn{1}{c|}{ Les plats } \\
\hline 1. L'Alsace & a. Le camembert \\
\hline 2. La Bourgogne & b. Le cassoulet \\
\hline 3. La Bretagne & c. Les cavaillons \\
\hline 4. La Bretaqne & d. La choucroute
\end{tabular}

Figure4. Example of remedial material (Géographie) 
As for the working methods, the approaches used in the remediation trajectory are varied. Here are some of the methods that were used:

- Working on self-study texts and exercises (with keys);

- Looking for specific information in reference books, publications and websites and answering questions;

- Getting familiar with the item: e.g. listening to songs or texts (e.g. YouTube), reading books or articles, following the news and reporting on it, filling in famous texts, poems, quotations, chansons, etc.;

- Developing a webquest or a portfolio on a cluster of items e.g. Découverte de Paris et ses monuments;

- Producing a class preparation or a project on a given topic etc.

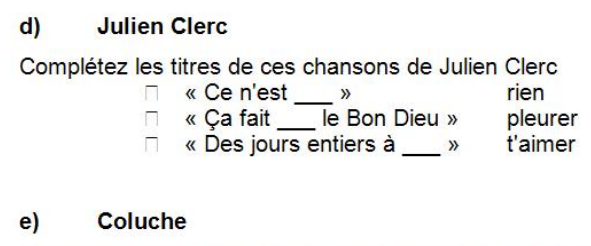

Quel est le nom du groupe de chanteurs qui chantent chaque année au profit des "Restos du coeur"?

Le groupe s'appelle « Les Enfoirés »

\section{f) Joe Dassin}

Joe Dassin est un chanteur français d'origine étrangère. D'où vient-il?

Des Etats-Unis

Ses chansons les plus connues sont " Et si tu n'existais pas », "L'été indien » et "Les Champs-Elysées ». Ecoutez-les sur YouTube.

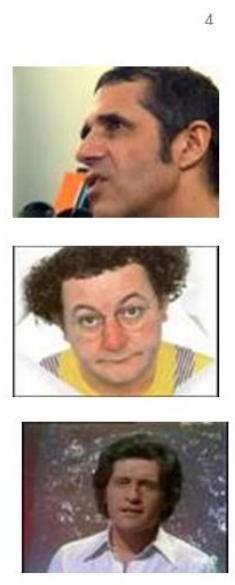

Figure5. Example of remedial material (Chanson)

Further fine-tuning of the content area in the remediation trajectory is decided in accordance with the student, depending on his or her specific needs. In the meantime, the student can ask teachers or assistants for support or feedback. When students complete their remediation trajectory, they can use the assessment instrument again in order to measure their progress. If they reach the minimum level, they are allowed to start teaching their practical lessons (in the second semester).

\section{Culture: An Integrated Part of The Curriculum}

For students starting their teacher training with shortcomings in their basic culture knowledge, remediation trajectories provide considerable support. Students without these apparent shortcomings went through the teacher training programme without paying extra or specific attention to their cultural knowledge. As teacher trainers we considered this was a missed opportunity, especially as, thanks to our corpus analysis (cf. Section III., A.), we had a clear understanding of the cultural elements present in French textbooks.

From this starting point, we decided to work further on these data and to include them in the curriculum. This led to a project on webquests called CultureQuests, in which all the students take part. Each student chooses a topic from the common bowl of cultural elements and works out a webquest (integration of ICT). These webquests are also linked to the levels of the Common European Framework of Reference (CEFR).

In this way, students not only increase their own knowledge of a specific cultural topic, but they are also introduced to their fellow students' topics, as they all make a presentation of their webquest for peer evaluation.

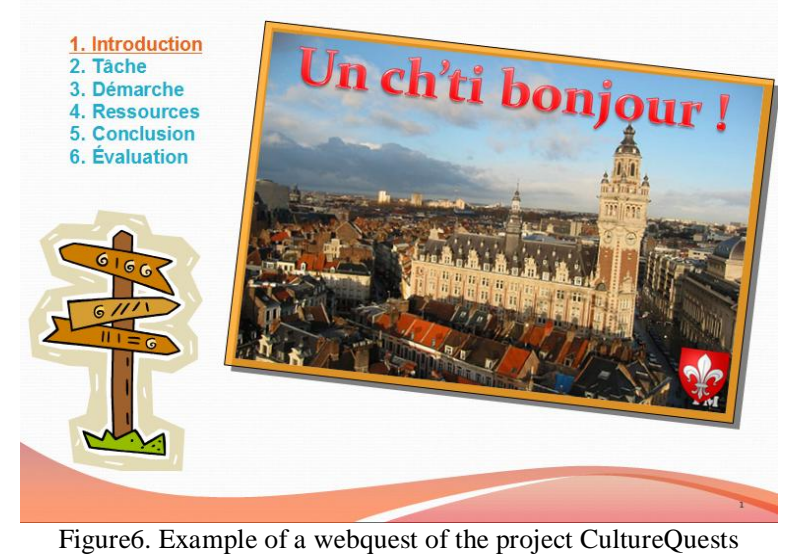


The webquests are made available online on the following site: http://www.ua.ac.be/didaktiekfrans .

This way, students are also stimulated in making a further use of this material in the frame of autonomous learning in their future jobs as teachers of French.

\section{CONCLUDING REMARKS AND RECOMMENDATIONS}

This article reports on efforts made towards developing basic content knowledge in the course of didactics of French as a foreign language, with an eye on improving future teachers' basic cultural knowledge. It could work as a source of inspiration for other language-specific didactics, as there is increasing concern about declining discipline-specific knowledge (cf. Kamp, 2007; Van Gennip \& Vrieze, 2008).

The importance of discipline-specific knowledge has been underlined in several studies. Therefore, sufficient attention should be paid to this aspect of education in teacher education. It should not be taken for granted that incoming students have sufficient discipline-specific content knowledge.

Language teachers' discipline-specific content knowledge includes both linguistic and cultural elements. In order to improve the basic cultural knowledge of future teachers of French as a foreign language, an assessment instrument and matching remediation trajectories were developed. The assessment instrument (available on Blackboard) provides detailed feedback on students' level. When students fail to reach the cut score, they can work on their shortcomings by themselves through outlined remediation trajectories closely reflecting the contents of the assessment instrument and available as electronic workbooks. While following the remediation trajectory, students are allowed to use the assessment instrument ad libitum, in order to evaluate their own progress. At the end of the remediation trajectory, they are evaluated by means of a summative test as a prerequisite for the practical lessons. Thanks to this project, cultural knowledge could be included as a central part of the curriculum. Each student works on a specific cultural topic and makes a webquest out of it.

For many, discipline-specific content demands are positive both for students and teachers. Good discipline-specific content knowledge and sound basic competences broadly determine what a good teacher is. This means that both in teacher education and in continuing education, attention should be paid to the acquisition of discipline-specific knowledge (and competences). Developing subject-specific knowledge is not an obstacle to graduating as a teacher. It is a basic attitude of teachers to keep up with their discipline.

This project enables us to formulate some recommendations for good practice, directed to language teacher trainers or teacher trainings willing to commit to discipline-specific expertise:

- Pay attention to content knowledge in teacher training. Content knowledge precedes the pedagogical content knowledge a future teacher has to develop. Teacher training programmes should deepen understanding and insight in these contents.

- As far as the development of an assessment instrument for content knowledge is concerned:

$\circ$ Focus preferably on the contents the future (language) teachers will have to teach themselves. Textbooks of the intended levels can be valuable tools in order to develop a corpus of contents.

- Include the contents in an independent database. Electronic learning environments (e.g. Blackboard) will not be used forever. An independent database offers the possibility to use the same contents for other pedagogical devices or tools (e.g. textbooks).

$\circ$ Give students the opportunity to practice as often as they want.

- Determine minimum levels: future teachers should not start teaching in real class situations if the minimum knowledge is not mastered.

- Pay attention to remediation: these contents should be closely related to the test contents. Remediation is only necessary for the domains the student/future teacher has lacuna in.

- Try to integrate content knowledge in the (broader) curriculum of teacher education. The development of webquests on specific (cultural) topics can be an interesting tool.

Content knowledge cannot be left to chance. Through remediation strategies, re-testing and links with pre-service training, students are likely to develop an increased awareness of its importance. Besides, they will also strengthen their self-efficacy beliefs.

Subject content requisites for teachers and pupils are (often) considered positive, The capacity to activate content and to acquire basic competences undoubtedly have an influence on determining what a good teacher should be. Therefore, more effort should be made, both in pre-service and in-service training, to acquire subject-specific knowledge (and competences).

\section{REFERENCES}

[1] Bruner, J. (1967). Studies in cognitive growth: A collaboration for cognitive growth at the center. New York: Wiley.

[2] Byram, M. \& C. Morgan. (1994). Teaching-and-learning language-and-culture. Clevedon: Multilingual Matters.

[3] Byram, M. \& G. Zarate. (1994). Definitions, objectives, and evaluation of cultural competence. Strasbourg: Council of Europe.

[4] Byram, M. \& A. Feng. (2004). Culture and language learning: teaching, research and scholarship. Language Teaching 37, 149168. 
[5] Essen, H.W. van \& M.C. Timmerman. (2007). Beter dan vroeger of terug bij af? Een historische reflectie op het 'nieuwe opleidingsparadigma' vor de pabo. Pedagogische Studiën 84, 224-232.

[6] Feys, R. \& N. Gybels. (2006). Taalonderwijs Nederlands \& methodestrijd: vervolg. Onderwijskrant 137, 26-40.

[7] Gennip, J. van \& G. Vrieze. (2008). Wat is de ideale leraar? Studie naar vakkennis, interventie en persoon. Nijmegen: Radboud Universiteit, ITS.

[8] Grossman, P. (1990). The making of a teacher: Teacher knowledge and teacher education. New York: Teachers College Press.

[9] Hill, H., B. Rowan \& D. Loewenberg Ball (2005). Effects of teachers' mathematical knowledge for teaching on student achievement. American Educational Research Journal 42:2, 371-406.

[10] Kamp, M. (2007). De leraar meester of slaaf van het leerplan. Velon Tijdschrift 4, 6-11.

[11] Liddicoat, A. J., Papademetre, L., Scarino, A., \& M. Kohler. (2003). Report on intercultural language learning. Canberra: Australian Government, Department of Education, Science and Training.

[12] Kendall, J.S. \& R.J. Marzano. (1997). Content Knowledge. A compendium of standards and benchmarks for K-12 education. ERIC - Educational Resources Information Center.

[13] Kleickmann, T., D. Richter, M. Kunter, J. Elsner, M. Besser, S. Krauss. \& J. Baumert. (2013). Teachers' Content Knowledge and Pedagogical Content Knowledge. The Role of Structural Differences in Teacher Education. Journal of Teacher Education 64:1, 90-106.

[14] Loewenberg Ball, D., Hoover Thames, M. \& G. Phelps. (2008). Content Knowledge for teaching. What makes it special? Journal of Teacher Education 59:5. 389-407.

[15] Neut, I. van der, T. van Schilt-Mol \& R. van Steensel. (2007). Taal- en rekenproblematiek Pabo-instromers. Tilburg: IVA.

[16] Onderwijsinspectie (2004). Thematische onderzoeken: Het onderwijs van het Frans in het Basisonderwijs en de aansluiting op de eerste graad van het Secundair onderwijs. Onderwijsspiegel, 95-103.

[17] Sercu, L. (2006). The foreign language and intercultural competence teacher: the acquisition of a new professional identity. Intercultural education 17:1, 55-72.

[18] Shulman, L.S. (1999). Knowledge and Teaching: Foundations of the New Reform. In: J. Leach \& B. Moon (eds.). Learners \& Pedagogy. London: Sage Publications, 61-77.

[19] Swerts, J. \& K. Monten. (2012). Een onderzoek naar de politiek-maatschappelijke, geografische, historische en economische kennis van studenten lerarenopleiding. Hasselt: KHLIM.

[20] http://vakdidactiek.be/sites/default/files/u128/Eindrapport\%20zonder\%20cartoons.pdf (accessed 19/2/2014).

[21] van Driel, J. (2009). De vakdidactische kennisbasis van docenten. Keynote presentation ORD- Onderwijsresearchdagen 2009.

[22] Verloop, N. (1999). De leraar. Reviewstudie, uitgevoerd in opdracht van de Programmaraad voor het Onderwijsonderzoek van NWO. Den Haag: NWO/PROO.

[23] Verloop, N. (2003). De leraar. In: J. Lowyck \& N. Verloop (eds.). Onderwijskunde: een kennisbasis voor professionals. Groningen: Wolters-Noordhoff, 195-232.

[24] Verloop, N., J. van Driel \& P.C. Meijer. (2001). Teacher knowledge and the knowledge base of teaching. International Journal of Educational Research 35:5, 441-461.

Mathea Simons (Belgium, 1 November 1972) graduated as Master in Romance Languages and Teacher education at the University of Antwerp, Belgium. She obtained a Ph.D. in the field of self efficacy in foreign language teaching in 2007 at the same university.

Before, she worked as a language teacher (French and Spanish) in secondary and adult education. She works currently as Assistant Professor at the Institute of Education and Information Sciences of the University of Antwerp, Belgium, where she is also vice chair of the Academic Teacher Training programme. She teaches French and Spanish L2 Education. Her research interests are in teacher education and professional development, new technologies in language teaching and foreign language teaching and learning. 